\title{
Patoemat (fragment)
}

\author{
Daniel Kamocki*
}

Przed Państwem stoi słodziutki chłopiec:

- „Jam Jacuś Majtek, a ten tu kopiec

$\mathrm{Na}$ wierzchniej stronie puszcza dwa bratki.

Zaś pod nim leży trup mego tatki,

Wygięty w geście delirium tremens,

$\mathrm{Z}$ mordą zdziwiona, że pełen kredens

Tylko przypadkiem zrobił fikołek,

Dając jej barwę — taka jak fiołek,

$Z$ raną czerwona, broczącą silnie

Zadaną w czaszkę butelką mylnie,

Bo miała pęknąć w toastów salwie

Wzniesionych papie przez tłumy larwie

Przejęte wspólnym wódki odorem.

Mój papo z nosem o linii torem

Węża esicy leży pod ziemią,

Gdzie zwłoki innych bliskich mych drzemia.

I doszło do mnie, co uczyniłem,

Podle mi teraz wśród was żyć będzie,

Bo głos sumienia przemówi wszędzie;

Gryźć mnie wyrzutem będzie po ciele,

Po moich drobnych rączkach, co wiele

Dźwigać musiały na co dzień w znoju

Zlewek i drewna, i pełnych gnoju

Wiader cynkowych - z kanalizacja

* Absolwent Uniwersytetu Lódzkiego i Uniwersytetu Medycznego w Łodzi, e-mail: danielkamocki91@ gmail.com. 
Był zawsze problem. Zresztą z kolacją

Nikt też nie czekał, więc w każdy wieczór

Zmęczony praca głodum już nie czuł,

Padałem w wyrko i nawet wtedy,

Miast śnić spokojnie zwinięty w bety,

Oko i ucho otwarte miałem,

Nad pobudkami ojca czuwałem,

By nóż stalowy, z którym naćpany

Chodził i ciął nim długie firany,

Krzycząc, że na nich jest mysie stado,

W nim wywołuje gorączkę bladą,

Nie trafił w któreś z nas tu leżących;

Tyle mych serce trosk wskroś palących

Przeżyć musiało w dzieciństwa czasie

I nie wiem teraz, czy upora się

Ze znojem bicia w mordercy ciele.

Wprawdzie awantur w mym domu wiele,

To tylko jedna kłótnia w ten sposób

Się zakończyła, że z dwójki osób

Jedna się żywa rankiem ostała.

W trosce, by sprawa się nie wydała, Przyjąłem wersję: wskutek padaczki

Męczacej papę, koniec utarczki

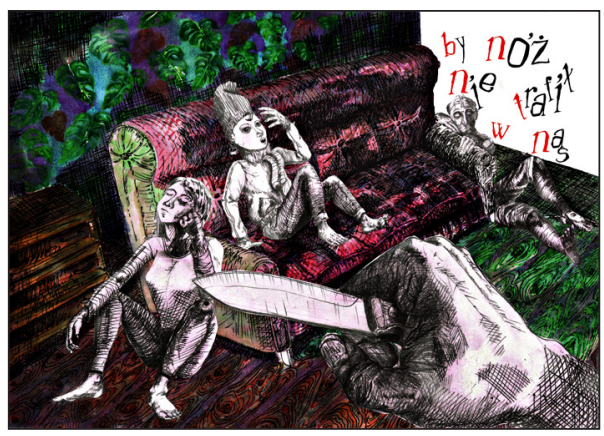

Nadszedł w tej chwili, gdy tatuś orła

Pierwszego wyrżną i z swego gardła, Zamiast strumienia „chujów i kurew”, „Ja was zajebię” i ,stajesz mi wbrew, Ty skurwysynu?" tylko wydobył Jęki, rzężenia. A nóż, co zdobił Do tego czasu tatulki rękę, 
Przejąłem pewnie, by przerwać mękę.

I dla pomocy pierwszej niesienia

Niepostrzeżenie do ugodzenia

Nożem w brzuch tatki w afekcie doszło.

Osamotnienie mnie wtedy niosło,

Bo taty wina, żem już sierota,

Choć szedł w zaparte jak ten idiota,

Trafił w pieszczoty mej ciężkiej dłoni,

I zaraz po tym zdrój z jego skroni

Strumieniem farby trysną gwałtownie.

Żeby uniknąć kontry raptownej,

Której doświadczyć mógłbym z rąk tatki,

Ciosem kolejnym za pamięć matki

Mojej kochanej oraz za babkę

Mózg mu utłukłem na krwistą papkę.

Jedno zaś tylko zadrą w me serce

To zaniedbanie kłuć będzie wielce,

Gdym, ojca bijąc, pieska krzywd mego

Nie wspomniał wtenczas; żal mi dlatego,

Żem go nie pomścił, gdy piszczał wczoraj,

Kiedy go ojciec wrzucił do wora.

Biedaczek na wspak w panice chodził,

Dodam, że bydlak trzy dni go głodził;

Z miski do żarcia zrobił wychodek.

Sił żem miał wtedy, by gówna spodek

Trafił mu tylko w ryj rzutem celnym,

Gdy tylko ojciec zrobił go pełnym.

Teraz więc pozbyć trupa się z domu

Oraz szkieł muszę, a czynić komu

By się to chciało, gdy z zewnątrz wspólnie

Tramwajów zgrzyty z szepty potulnie

Plantów płynęły melodią taką:

«Z kamienic rzędów podobnych wrakom

Statków pirackich psów chmara wściekła

O barwie tęczy szybko wybiegła.

We wrzasku słychać wycie znajome.

To pies Jacusia stał się już wodzem

Włochatej bandy i ze śmietnika,

Na który susem wskoczył z chodnika

Ujada w cudzej i w swej intencji,

Dając tym samym upust pretensji

Kapciem po grzbiecie bitych zajadle,

Gdy zwiną z kuchni świńskie podgardle. 
Z człowiekiem rozbrat bez odwołania

Bierze nieczułym na od zarania

Dziejów relację w podaniach snutą,

Pieśniami czczoną i w brązie kutą».

Kiedy do uszu Majtka dobiła

Melodia z miasta, wnet myśl spowiła

Jacusia głowę, by wśród tych dźwięków

Znaleźć do psa trop bez żadnych względów.

Wybiega Jacuś w rumor uliczny,

Przechodniów trąca i choć cyniczny

Być się wydaje, to tak na serio

Za psem jest uczuć pchany feerią.

Tęsknota, smutek i wizja straty

Czynia go zgoła innym od taty.

Maryi Matce bliskim, co więcej,

Się staje Jacuś; bucha goręcej

Od niego żalem, gdy nieść modlitwie

Takiej się daje w miejskiej gonitwie:

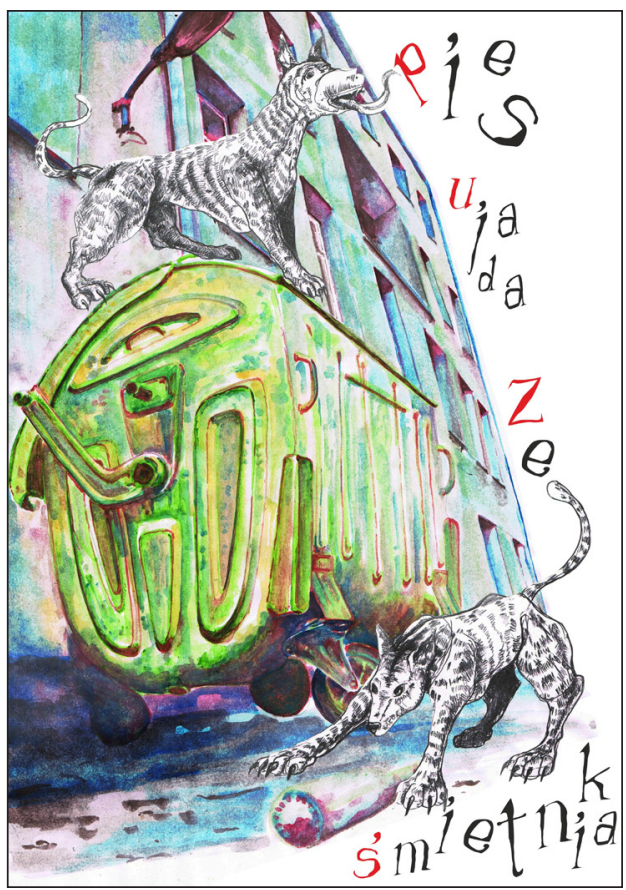

Daniel Kamocki · Patoemat (fragment) 
„Trzymać na rękach Dziecko Boże

Wodza narodów i ścięte zboże.

Smukłego chłopca danego Słowem.

Ofiarę ludu i dojną krowę.

Trzymać i płakać nad swą niedolą, Straconym życiem i Boską Wolą, Żydowskim prawem oraz samotnią, Licho się tlącą tu się pochodnią. Płakać i wołać do Boga Ojca, Matek wyrodnych, których płacz z kojca

Dzieci zaszczanych wcale nie zmieni, Do katów, co łzom są głuchoniemi.

Wołać i jęczeć, od łez się ciężkich Kropel zanosząc, w obliczu klęski, Tłumionym żalem, bolącą duszą, W chusteczki ściegach swe oczy susząc. Jęczeć i cierpieć, lejąc łez morze, Tuląc się w zwłoki, w ślepej pokorze, Przez która greeting anioły słały, Od ran ukutych w marmurze białym.

Cierpieć i krwawić ranami syna, Wybroczynami koloru wina,

Sercem pękniętym, blizną w przegubach,

Gwoździem szarpana, ostrym bólem, ach!”.

I rozedrgany mieszanką wrażeń

Z dotychczasowych fatalnych zdarzeń,

A także kłębem myśli o psiaku, Błądzi po mieście z poszlaki braku.

Wchodzi przypadkiem do stojącego

W korku tramwaju, na grożącego

Pięścia przechodnia, którego wcześniej

Popchnął w pośpiechu, biegnąc po mieście,

Nie zwrócił nawet swojej uwagi,

Bo wkroczył Jacuś w świat pełen magii.

W kłębie utkanym dymem Pall malli

Jawi się zarys białych korali

Na szyi smukłej luźno wiszących.

Potem woń perfum zewsząd bijących

Zdradza obecność smutnej kobiety

Myślą zajętej - a nie kokiety.

- „Hej, mały!” - woła, a wzrokiem błądzi

Po siedzeń rzędzie, oczy jej mąci

Żalu łza gorzka. - „Dokąd Ci śpieszno? 
Drogę zgubiłam, głupio tak, wiesz no.

Jadę bez celu, a dostać się chcę

Do cyrku «Patol», ibizą swą mknę

Zwykle tam co dzień, bo bawię gawiedź,

Na linie skacząc. Zobacz sam, zajedź.

Zapomnisz prędko o trosk dnia skazie,

Jestem spóźniona, mam auto w gazie,

Na przegląd grata dziś odstawiłam,

Ja się natomiast nie przedstawiłam.

Jestem Irena, chodź no tu do mnie".

- „Jam Jacuś Majtek”. - „Trochę frywolnie,

A któż to imię takie Ci nadał?”

- „To tatki wina, on to wykradal

Mamie na moje rychłe przybycie

Ciułane przed nim pieniądze skrycie.

Drobne na kaszkę, kołyskę, leki,

Pieluchy oraz ciuszki, co ściegi

Wzorzyste mają, podły drań wydał.

I majtek parę do dziś za przydział

Skromny i wiano mieć mi przypadło".

- „Nadal je nosisz?” - lico jej zbladło,

Gdy pąsem oblan ze wstydu Jacuś

Tłumaczył się więc, jaki tam pracuś

Z niego jest jeszcze; na nowa parę

Nic nie zarobi, że prędzej karę

W sądzie nieletnich za szwarce arbeit

Dostanie pewnie, że życie to fajt

Jego jest $z$ ojcem i że nikt prawa...

- „Dobrze, już dobrze, strasznie nudnawa

Jest twa historia, bo wiesz, ja w cyrku,

$\mathrm{Na}$ linie skacząc, pełno już świrków

Z przeszłością różną poznałam takich:

Cwele, złodzieje, podłe łajdaki,

Mordercy, chlory, dziwkarze, szuje,

Wykolejeńcy i podłe chuje.

Wiedzione życie przez nich dotychczas

Pachnie jak wszystek występków wykaz.

Jeśliś jest gotów, to Ci opowiem,

Jednak mi pokaż, bo nadal nie wiem,

Jak do «Patola» dostać się mogę?"

- „Pierwszy raz słyszę, choć przez próg nogę

Twojego cyrku chętnie przełożę".

- „Na nic twa pomoc i jak ja, Boże, 
Na próbę na czas mam się pojawić, Żeby widownię w paraliż wprawić?

Dziwne to miasto z tą puchą mknącą,

Co chwilę staje, a ja gorącą

Chęcią zjawienia się już na scenie

Wewnątrz się palę. To nie są brednie, Że chcesz obejrzeć popisy nasze?

Wprawdzie już pora, tak mówi gwaszem

Plakat malowan”. - „Nie widzę, gdzie on?” -

- Głowę odwrócił i trochę zlęknion

Ujrzał na szybie poster ze słoniem,

Lwem oraz strusiem, wyciągnął dłonie,

By się przekonać, czy to nie złuda.

Ściagnął więc plakat, wtem małpa ruda

We wściekłych pląsach susa znienacka

Zrobiła prężnie na głowę Jacka.

Pozbyć się chłopiec małpy próbował

Na chybił trafil, ale spudłował,

Gdy zamach głową o trapez zrobił.

- „Przeklęte zwierzę!” - a guz ozdobił

Główeńkę moją, ten trapez skąd tu?

Wziął się on znikąd, wyjęty ze snu?"

Wierzgając ślepo, w potknięciach wielu

Zwiedzał jadący tramwaj bez celu

I zdjęty lękiem, że dotąd bliski

Pojazd z dziewiątką zwrot na Kaliski

Dworzec przyjmuje. Razem z zakrętem

W Gdańską ulicę pada jak prętem

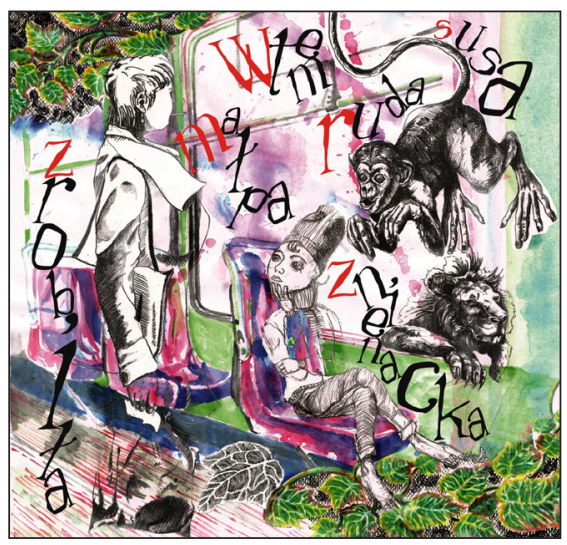


W nogi uderzon i na myśl przyszły

Mu ojca razy, lecz żale prysły,

Gdy mokry jęzor na stopie poczuł.

To lew z plakatu. Plamka na kroczu

Ze strachu przed lwem na Jacka portkach

Się pojawiła. I tylko „Och, ach!”

$Z$ ust się wyrwało chłopcu, co naraz

Z ziemi się podniósł. Małpa też zaraz

Skoczyła chyłkiem, łapiąc za klamkę

Sterczącą z góry, znoju ułamkiem

Okno na oścież w dachu rozwarła,

Przez nie wybiegła i moca gardła

Polesie jękiem całe objęła.

Lwa ta afera wkurwem przejęła

I ryknął gniewnie, jęk małpi bijąc.

Gapie zdziwienia jawnie nie kryjąc,

Tramwaj przecięli wzrokiem od razu.

Gość jakiś autem, mimo zakazu,

Wyjechał z piskiem w stronę tramwaju,

Mkną tak beztrosko jakby na haju.

Podkręcił głośnik i z radia znana

Piosnka leciała przez zespół grana,

Który atrakcją dnia na posterze

Przedstawion został. Oto w eterze:

„Z butelek barwnych w kalejdoskopie

Widać jak ktoś tam menela kopie.

Kopie i pluje w bramie zaszczanej,

Ktoś tam ucieka, menel zostaje.

Po peta łapa z chodnika sięga.

A na niej blizna i sina pręga.

Nie myśli o tym, że ledwo dycha.

Zaciaga się nim i ostro prycha.

Zamiast „Ratunku!” krzyknąć „Pomocy!”

Pozwala śmierci zajrzeć w swe oczy.

Kiedy kostucha swe powinności

Czynić zaczęła, o wielkie mdłości

Fetor menela wnet ja przyprawił.

- ,Jak stara jestem, żaden nie strawił

Mych nozdrzy jeszcze odór piekielny.

Od czarcich bąków z głębin podziemnych,

Cerberzych klocków, Syzyfa potu

Tak nie ciągnęło mnie do wymiotów Jak od twojego ciała fetoru. 
Nic już tu po mnie. Nabrać koloru

I tlenem świeżym odetchnać muszę,

Spadam, a Ty cierp tutaj katusze,

Czerwiom niestraszne truchła odory

Czynić im oddam swoje honory".

Tak oto z śmiercią życia potyczkę

Menel wygrywa, potem w uliczkę,

Gdy tylko powstał i się otrzepał,

Krokiem, co trochę mu się pojebał,

Bo miast na zmianę iść: lewa, prawa,

Postapił przed się, aż nagle czkawa,

Zwrot mu do tyłu o krok zmieniła.

Prędkość się auta nagle zwiększyła

Aż oczy gapie z lwa pościągali

I, myśląc sobie, że postradali

Ci dwaj kierowcy swych zmysłów resztki

Włosy rwać gapie po same mieszki

Zaczęli w strachu przed kraksą straszną.

Mkną dwa ku sobie ulicą ciasną

Czołem naprzeciw pojazdy tnące

Smuga powietrze i tylko tlące

$\mathrm{Na}$ ich krawędziach się cząstki jawią,

Które swym żarem nadwozia trawią.

Skrzą się kolejno: od farb czerwieni

Poprzez pomarańcz aż do zótcieni,

Po czym to głośny huk zrazu słychać,

Jednak rozbitych części nie widać,

Bo chmura dymu niczym zasłona

Przykryła zajście i jakby z łona

Wyłaniać się z niej wspólnie zaczęli

Dwoje grubasów, co się objęli,

By równowagę w pochodzie trzymać,

Podczas którego trzeba wydymać

Im brzuchy tłuste i szkłem po piwie

Żonglować zręcznie. Dalej w porywie

Za nimi idzie luj smrodem tchnący,

Stadkiem pcheł własnych po łbie skaczących

Się popisuje, drogę toruje

Dresom, co w czwórkę, jak głupie chuje,

Piłkę do siebie kopią z kolanka.

Za nimi Sebek, przed nim wybranka,

Dżesika, spieprza z razów śladami.

Odziana tylko łachów strzępami 
Gwałtownie staje, stanowczym głosem

Mówi donośnie, a nie pod nosem:

- „O przed zachodem magicznej porze

W betów refleksach wlał w nią swych morze

Wrażeń całusem i niesion dalej

Chucia palaca, coraz zuchwalej

Jej plecy pieszcząc, wzdłuż nich się zsunął

I w bioder splocie w jej lędźwie runął.

Jak ruchem tłoka napiera całem

Potem zroszonym swym smukłym ciałem...”

- „Do kurwy nędzy, do domu wracaj,

Bo sterta garów już się przewraca!" -

- Słyszy Dżesika od Sebka swego.

Z jej karku kapciem krew trafionego

Się wydobywa. Dżesika zrazu,

Od bólu łkając, Sebka rozkazu

Się nie ociaga spełnić sumiennie.

Wkracza w idący pochód niezmiennie,

Który dotychczas z Gdańskiej ulicy,

Co szlak z niejednej to kamienicy,

O bramach moczem i oknach dymem

Znaczonych dawno (że nawet z Rzymem

Równać się może), sklepowej budy, Banku i knajpy (z której woń wódy Jest zapowiedzią pijanych klientów, Którym wciąż mało we krwi procentów, Bo wyrzuceni na bruk kopniakiem, Leżą se na wznak pod stopu znakiem), I z niejednego parkingu także Miał ułożony. Procesja wszakże

Idzie Zieloną, tratując ludzi, Drzewa i słupki. Minąć nie trudzi

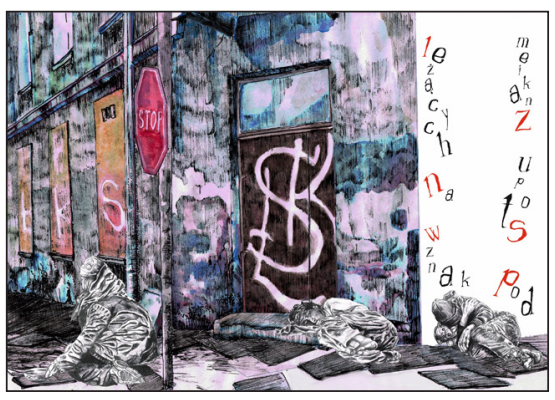


Przeszkód się pochód. Oknami swymi

Patrzy z fasady kolorowymi

Liźniętych czasem, erozją, pleśnią,

Niedbalstwem, brudem, mieszkańców cieśnią,

Sznurek kamienic supłany wspólną

Mroczną historią, którą okólną

Nawet metodą żyjący jeszcze

Streścić się boją, tylko na deszcze

Ulewne czekać trzeba, by zmyły

Brudy, co miasto to osławiły.

$\mathrm{Na}$ tłum niejedna budowla patrzy.

W dachy zachodzą, plotą trzy po trzy

Rzucone w szereg ponad ulice

Z siwymi gzymsy te kamienice

O tym, co widza: - „Ostatnio kiedy

To tylu ludzi między nas w rzędy

Dwa ustawione parło szalenie?"

Żółtej budowli szept z drzwi waleniem

Się zbiegł sąsiadki, rolet ściąanie

Drugiej budowli wycisza zdanie:

„To za komuny, gdy wysiedlone

Ludzi biegały tłumy szalone”.

- Poza wypadkiem auta z tramwajem

Nic się nowego nie dowiedziałem". -

- Wspomniał beżowy świstem powietrza

Budynek pusty o pustych wnętrzach.

- „Czyżby więc ten huk sprzed kilku minut

To też był unfal, strzał jak z karbidu?” -

- Z bramy wyrwało się piętrowcowi,

Z której to dobiegł ujadań skowyt.

$[\ldots]$

Tekst jest fragmentem niepublikowanego utworu

Daniela Kamockiego Patoemat

Ilustracje: Daniel Kamocki 